\title{
A Gum-Tree Exile: Randolph Bedford in England and Italy
}

\section{Lucy Sussex, University of Ballarat}

London has for most of Australian history served as a magnet for the gifted and aspirational. This feeling was particularly strong and optimistic at the turn of the last century, when Melba was Queen of the Opera. Many followed her example in travelling north: musicians and theatricals, but also artists, writers, and journalists. Of those who felt this siren call, very few would actually succeed. Henry Lawson would become the most famous example of this failure, with his sojourn in England something from which he would never recover, personally and artistically (Tasker \& Sussex 2007).

Lawson's friend Randolph Bedford (1868-1941) was a very different case. A gifted journalist and crime writer, Bedford had talent, ingenuity and boundless energy. Like Lawson, he made the trip to England, and emerged from it with a preference for Australia. It might at the time have been considered heresy, but he profoundly rejected the motherland. Instead he chose to employ his considerable abilities in Australia and for Australia. The decision was pragmatic, emotional, and proudly nationalist. Unlike many of his contemporaries, it was not fired by a sense of failure in England, the dire financial necessity of return. Bedford was of independent, approaching wealthy means. Moreover, he would place two novels with English publishers. The leaving of London was perhaps the strongest expression of his identity - for he had a powerful personality, being of strong opinions, an Australian of the type positively categorized in Keith Dunstan's 1979 study Ratbags.

Bedford as a writer has not received much recent criticism: he makes a small appearance in Peter Morton's Lusting for London (2011); and has attracted scholarly 
assessments by Ros Pesman Cooper (1990) and Cheryl Taylor (1999). He deserves more attention, for he was a unique phenomenon, equally skilled with the pen, mining speculation, and politics. As a teenager he 'tramped to Broken Hill with Carlyle's French Revolution in his swag. That book coloured his life' (L. Lindsay 1967: 61). Politically he was the eternal socialist. He began his writing career as a journalist, on the Broken Hill Argus, and from it learned about mining, from which he made several fortunes, whilst still retaining his socialism. He ended up as a Queensland politician, of nationalistic, protectionist politics, and a 'big hat' as his son Eric later described him (1957). Bedford was a poet, not only voluble, but also highly articulate. In his autobiographical novel, True Eyes and the Whirlwind (1903c), Bedford is the whirlwind, which pretty much sums up his effect on people. He also used the pseudonym Randolph the Reckless. Perhaps the best depictions of Bedford emerge from his association with a family of artists, the Lindsays, who drew him acutely, both visually (figures 1 and 2) and in prose.

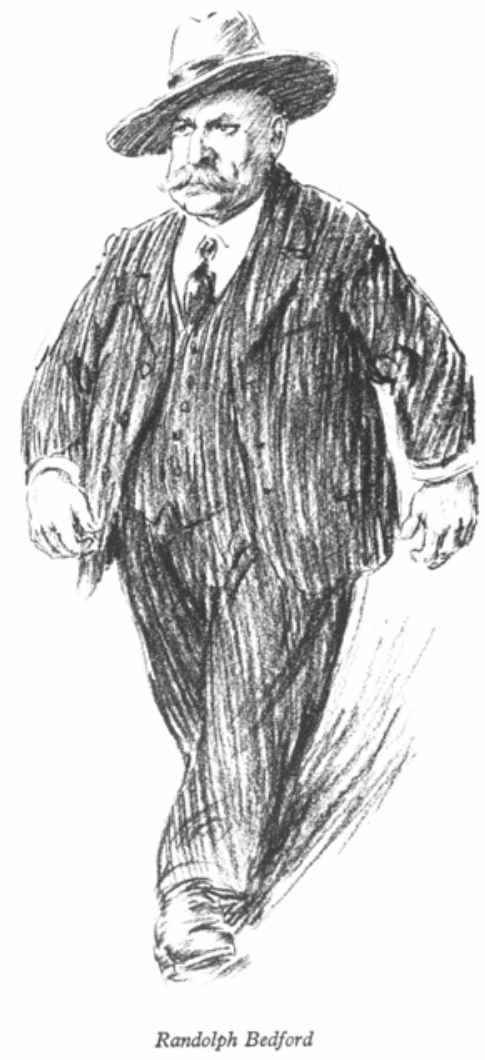

Figure 1: Bedford by Norman Lindsay, from Bohemians of the Bulletin (C) H., C. \& A. Glad. 
Lionel Lindsay made a lifelong friend of Bedford, from which arose his marriage: Jean Dyson (of the Dyson family of illustrators) had accompanied the Bedford family as a companion to Europe, and when Lionel met up with them, romance blossomed. Norman Lindsay thought Bedford something of a bully, and noted his 'hooked, predatory nose ... hard, coarse mouth' (1965: 101). But in the best of Bedford's writing, his autobiographical journalism, he proves a sensitive observer with a strong aesthetic appreciation, whether of art or nature. Most commentators on the man note his chivalry and generosity to those in need, all the better if he could cock a snoot at the same time - as when he danced with an old matchwoman outside London's Press Club, gave her 'half a sov.' and paid for her cab ride home (L. Lindsay 1967:198-99). The blustering man of action was only one aspect of his character.

Both brothers agreed that Bedford was a master of entertaining narrative. Lionel recalled that 'no one since Adam pitched a better or a merrier tale' (1967: 61). Norman provided more detail: 'Most of all, he was gifted with a flow of words delivered with such speed, precision, emphasis and lucidity as I never heard equalled by any other exercise in volubility. Truculence was its accent, and there was a punch in every phrase of it ... He was magnificent company and the best raconteur I ever listened to' (1967: $102,106)$.

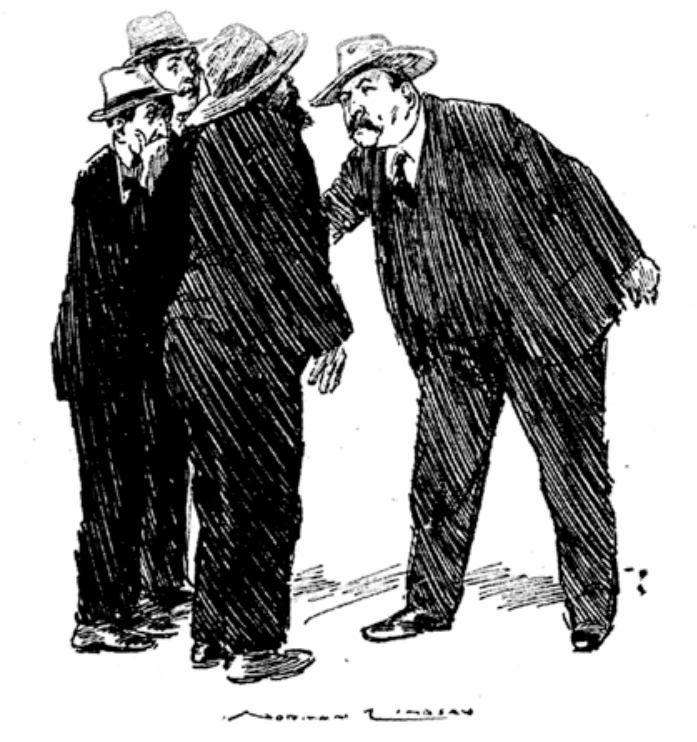

Norman Lindsay's heartfelt comment on himself, brother Lionel and $A$. G. Stephens dumbfounded by Randolph's eloquence-
which must have been torrential to have overwhelmed any one of them. 
By the 1890s Bedford had established an identity both as a successful mining journalist and speculator, and as a writer for the Bulletin. He had only narrowly failed at being elected as a Liberal to the Victorian parliament, despite having Labor sympathies. He would call Labor the 'only Australian party,' and join after Federation (Boland 1979). That same year, 1901, he took himself and his young family to England. He had various speculations to offer to English backers, he had a novel, and also a sick child for whom a sea-voyage had been recommended (Bedford 1976 [1944]: 326).

Bedford's lively autobiography Naught to Thirty-three (1976 [1944]) ends just before his trip to England. However, records of his overseas trip exist in two forms. He wrote back his travel impressions to the Bulletin and other periodicals from 1902 to 1904. The articles can be described as applying Furphy's dictum of 'temper democratic, bias offensively Australian' to the travel memoir. ${ }^{1}$ Taylor notes they 'perfectly matched the bumptious energy of the Bulletin's style' (1999: 39). These texts, which will form the basis for the examination of Bedford's abilities as a travel writer in this article, were collected and published together as a book, Explorations in Civilization, in 1914. The reason for the delay in book publication is unknown. Lindsay's cover summed up its

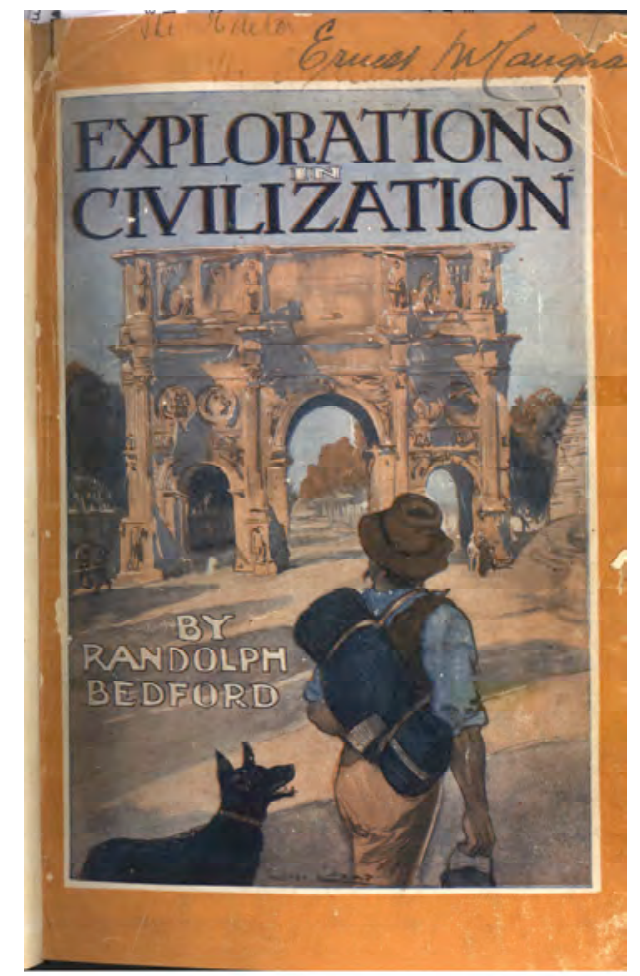

Figure 3: Lionel Lindsay's cover for Bedford's Explorations in Civilization, National Library of Australia, 2351277.

\footnotetext{
${ }^{1}$ Joseph Furphy, letter to J. F. Archibald, April 1897, cited in Barnes (1981: xv).
} 
content perfectly: the swagman in front of Rome's Arch of Constantine with his billy and dog, and his swag probably containing Carlyle's French Revolution (1837). The cover (figure 3) perfectly expresses Bedford's self-image, although he was not visiting Italy as a swagman or tourist, but rather investigating the possibilities of Italian mining.

When the original articles are compared to the 1914 book, it can be seen that generally Bedford saw no need to rewrite- passages re-appear word for word in the collection. He did however cut, losing entire articles. His original sub-title, which appeared at the top of each Bulletin instalment, also went: 'Being the letters of an Australian in Exile.' It had been a statement of intent, deliberately inverting the conventional attitude of the first generations of colonial Australians, the 'exiles we.' Homesickness for Australia pervades his travelogue; in Italy he wrote: 'Do not look upon the gum-trees-we are here exiles also' (Bedford 1914: 114).

Bedford took a dislike to England from his first sight of the cliffs of Dover, which he found 'not white but a dirty grey. Up to the feet of the cliffs the saddle-coloured Channel staggered and there was neither colour nor sunlight in the scene.' On taking a train to London, he was met by fog, and commented: 'So the miracles that brought me over 12,000 miles of sea had really happened, and this was London. It seemed such a weight of endeavour for such a light result.' Other expatriates, such as Louise Mack might have found England initially unprepossessing, then revised their opinions. Bedford did not: unimpressed he quickly moved to dislike and even loathing. 'And I begin to feel like howling for a sight of Australian sun — to lust for a clean atmosphere as a sailor for port and shore leave, or a bullock for milk-bush in drought-time' (1914: 20; see also 21, 27).

His concern with sun and clean air was not simply nostalgia. He was concerned for his sickly son Eric, and elsewhere noted the effect of England on Australian expatriates in decidedly unhealthy terms: 'I met two girls who were born Australian and become English. They loafed in fluffy tea gowns in a heated sitting-room where the air was an unnatural as chiffon. I was so depressed by the change from healthy women to demoralized dummies, that I left the house feeling the shame of a cat going home in the dawn' (1914: 35). The conservative, pro-Empire magazine the British Australasian noted Bedford's arrival and his hopes of a long stay 'where the versatile scribe hopes to exploit a novel, a book of verses, and a gold mine' (1901: 1986). The 'exploit' was 
probably a verbatim quotation from Bedford. In his quite justified self-confidence, he regarded himself as a rich resource in several apparently disparate but related fields. Mining speculation was his living, and informed his journalism, his autobiographical writing, and even his crime fiction. In coming to England, unlike Lawson, he had several strings to his bow, and could move between them with ease.

What would the English make of this larger than life bon viveur, so boisterous and noisy that he gave Lionel Lindsay's Bloomsbury landlady the shudders (Palmer 1963: 21)? And more importantly, what would he make of them? The Bulletin reported his first public appearance at London's Press Club: 'Randolph Bedford, on Australian experiences, lied lovingly and absorbingly_ so much so that the Club rose in a body and knighted him as an honorary member' (1902: 13).

Although he impressed the journalists, the publishers were another matter:

My novel has been read by two publishers, and one of them has strangulated hernia, and the other an aneurism as a result ... They wouldn't mind my being unconventional if I were Imperialistic, but, as a publisher's reader said to me the other day: 'To be unconventional and Conservative, all right; to be Conventional and republican, good, but to be Unconventional and Republican - it's too much.' (Bedford 1902: 2)

True Eyes was overlong at 250,000 words (Bedford 1976 [1944]: 272). A likely issue also would have been its sheer Australiana. Lionel Lindsay, whose time in Europe overlapped with Bedford's, recalled a sub-editor telling him: 'Actually the British public is not a scrap interested in outside things' (1967: 193).

Finding London backers for his mining and other projects also proved difficult. Bedford recorded other hopeful Australian speculators passing time in pubs waiting for the Boer war to end (1914: 26). He fruitlessly courted financiers whom, in the conventional, unthinking anti-Semitism of the era, he categorizes as 'Jews,' but with less venom than he described the non-whites he encountered during the steamship voyage to Australia. 'And when I see the sloth that comes to the white, from long association with the black, the hope that Australia will keep herself white becomes almost fanatic. For the slave owner is lower than the slave' (1914: 16.) Elsewhere he was insulted by the assumption that Australia was a poor investment prospect because of its socialism. He retorted: 'New Zealand has had a bellyful of socialistic legislation, as you call it, and has vastly 
improved under it; and England has had Tory legislation always, and couldn't be worse than it is' (1914: 153).

If he didn't get money for his mines or a planned massive Northern Territory agricultural venture, then he got material for his columns, and the sheer pleasure of insulting the self-important. One financier he visited had an office Bedford described as a 'packing-case.' Bedford's proposal was too small for him, he claimed, condescendingly, for he only dealt with millions. Not in notes, surely, Bedford responded, for 'you couldn't find room for anything bigger than a cheque in your office' (1914: 31).

Then, his luck turned, with a consortium including London's Lord Mayor sending him to Italy to investigate mining prospects (L. Lindsay 1967: 208). Here like many Australians, such as his contemporary, Sydney writer Louise Mack, he fell in love with the country. He and Mack were pioneering in this regard, their enthusiasm for the food, the art, the architecture precursive of many later artistic tourists from the Antipodes. At the time the climate of Melbourne and Sydney was not termed Mediterranean, but Bedford would note the similarity to Italian weather.

His rebellion against England and attachment for Italy were part of his radical nationalism, but also stemmed from his dislike for the Empire's stifling conventions. He recalled being told by an English writer in Australia that "no Australian would write good literature' until they had visited Westminster Abbey (1903b: 35). What he said in response he does not say, but the Abbey left him unimpressed, and with no apparent effect on his writing.

In Italy, a country in which he and Mack had no ancestral links, they felt at home. At Monte Rombolo this irreligious man felt such an affinity with history and place that he found himself speculating on his past lives. In a striking passage he travels in time, from being merely a tourist at a ruined castle to imagining its thirteenth century brigands, besieged by the Papal armies: 'I felt I had been in the fight' — which he describes in melodramatic and bloody detail, in the first person, even imagining the robbers slaughtering their women lest they starve or end as spoil for the Papal forces. He writes the past, with himself as participant, then notes: 'Given interest and imagination, many lives before this life seem very real' (1914: 39-40). 
The next paragraph goes further, both in time and bloodshed, with Bedford a Roman slave in a copper mine: 'One day I killed the overseer, and fled - through the oak-scrub and the gullies of cyclamens to the fields of lupins and the ripening grapes; and so to the sea. There I found a boat, and would have put safely from shore; but seeing a woman bathing — her white body argented in the moonlight—I waited' (1914: 40). His past self attempts abduction, with a resultant bloodbath, in which both slave and the woman die. 'These are but two of the Things I Think I Did,' commented Bedford, quite unabashed at the alarming glimpse he has offered of his psyche (1914: 40).

More typical was his insistence on seeing Italy in Australian terms. Taylor has commented that: 'By relocating the field of conquest in the coloniser's own countries, these articles impose an aggressively colonial system on Bedford's Old World experience' (1999: 39). But equally Italy conquers Bedford, aesthetically and emotionally. The psychological term 'transference' is applicable here, as Bedford's sentimental Australian nationalism finds a new home. South of Genoa he found 'curiously like Tasmania. There is a bay like Penguin and another like Emu Bay' (1914: 37). He never expresses this sense of déjà vu with English landscapes. In Italy his powerful nostalgia - to take the word apart and examine its roots - is a nostos, a homecoming without the pain of algia, but rather with pleasure reinforced by the perceived familiarity. Even when the classics inform his perception of the landscape, as might be expected from the contemporary well-educated traveller, he still manages a plug for Australia: 'There were more Horatian groves and Anacreontic rocks, and all the outlook was wide and deep and high and majestic for space: all with the inspiration of a big country like Australia, which is a name to be said with trumpets' (1914: 38). Back in London briefly to consult a medical specialist, he saw Ellen Terry play Beatrice in Much Ado About Nothing. Its Sicilian setting aroused his emotions: 'Italy tugged at my heart strings' (1914: 166). Although quite ill, he immediately fled back there, a non-stop journey of over forty hours.

Bedford, with his socialist, bohemian, irreligious propensities, might find Italy both priest- and aristocrat- ridden, but his descriptions of it are among his finest writing. It would be Italy rather than England that released his aesthetic sensibilities. The travel writing he produced there is vivid, as when he accompanies three working-class girls on a frog-hunt: 
I went with them to a swamp, where many frogs made raucous music; and with a disregard for my presence, which was very unflattering, the girls kilted high their skirts and entered the swamp, sweeping bog, and rush-hummock, and water, and green slime with their lanterns. Frogging is very simple. The frogs - great, green, swollen, swaggerers - came to look at the light and were seized and put into the bags.

We started on the return journey and in an accession of chivalry I asked to be given a burden. Angela assured me I wouldn't like the experience, and I didn't. I carried that bag fifty yards and then gave it up. Can you imagine the awesome clamminess of carrying a thin bag, stuffed with palpitating, squirming, swelling frogs, and green pap?

The kitchen, when the bags were opened, was like Egypt during the Mosaic plagues. The frogs were very ugly in their green clothes--and looked uglier when with one sharp knife-stroke they were gutted, and with another, beheaded. Some of them escaped and leapt blindly in the light. I trod with my bare foot on one brute, in all his necropolitan clamminess when I went to bed that night. But next noon, for collation, there was a great dish of them-mostly of hind legs fried in batter - and they were good. I ate many a score of them - they taste between chicken and Murray cod. (1914: 96-97)

As ever, he anchored his Italian experience with a reference to Australia. But the sojourn in Italy was not all pleasure: it also involved hard work and heartbreak. He wrote, in one of the few mentions of his family and domestic life: 'There was a death, and the grave of a child of my name in Gelsomino' (1914: 151). Later, when seriously ill, he experienced a nightmare in which Florence became the setting for a thoroughly disturbing and violent expression of his grief. Like his imagined past lives, it is revealing of his psyche. In his dream, Bedford walked the historic streets, twenty-five feet high, and with joints of steel. Around him clustered children, no more than a foot high, which he trampled, and even dismembered. A final child he recognized as his baby son Florio- 'And as I awoke I caught that child and killed him.' The whole is delivered to the reader without self-consciousness or much self-reflection. Bedford blamed his illness, with the jarring explanation that: 'There is still exudation of the lower surface of the intestine.' His opinion of Freud is unknown, but his self-image as a man of action would probably not have permitted being a subject for psychoanalysis, despite the dream's obvious symbolism (1914: 174-75).

The tragedy apart, and not making any money out of Italy (except via his writing), the experience delighted him. It sharpened an aesthetic sense already heightened by the association with friends like the Lindsays. He rhapsodized about Italian art as much as its landscape, even when cocking his typical snoot by insulting Ruskin, and making comments like: 'the bourgeoisie [sic] idea of art is the same the world over-they love only the pictures that a Wesleyan could paint' (1914: 93) 
If anything the overseas sojourn increased his love for Australia, in Italy by the affinity he felt, and in England, the absolute reverse. Nor was he alone in this opinion of England. During a brief sojourn in England, between episodes of Italian mine-hunting, Bedford and his wife Mary visited the Lawsons. Bertha Lawson would write that the visit 'gave us tremendous joy' (1943: 74). Bedford left an account of this meeting, not in the book, nor in the Bulletin, but in the Adelaide magazine the Critic, whose editor, Alfred McKain, also had a mining journalist background. Although Lawson is not named, it seems possible that the mention may have kept the piece out of the Bulletin, which was slowly coming to terms with the perception that Lawson had returned from England a broken failure, and a drunk.

I went to see a friend - an Australian writer who has made a bigger stir in Australia, where his work is known and rewarded, than he ever will here. He lives beyond Islington, and curses England, crying to be delivered from the body of this death and to be set down in an Australian sun again. If ever he says a good word of the country it will be from sheer perversity. After leaving him I walked for two miles through a street which was like the way between the stalls in old Paddy's Market, Sydney; squalor everywhere - two women to every three men in the drinking shops; cheap and nasty fruit and suspicious vegetables in barrows - oil torch-lamps flaring over all, and chilblain-faced people, wet-nosed people, cold people everywhere. (Bedford 1903a: 13)

And so Bedford ends as he began, with not a kind word for England.

Bedford was a generous man, and it seems that some of the joy Bertha Lawson reported was financial. Lionel Lindsay recorded that Bedford 'found Lawson and his wife living in a slum, and helped them.' He added that 'how they managed to get back to Australia I never learned.' One possible interpretation here is that Bedford at least partly footed the bill. Only five pages earlier Lindsay records his own exit from Europe, paying for his third-class passage with money he had borrowed from Bedford. Other Australians abroad attested to his generosity. Illustrator Frank Nankivell, when in New York in 1923, and needing 'a few hundred dollars ... very badly' asked Randolph, not knowing the big man was 'short.' Nankivell got the money, and found out later Bedford had cancelled his berth on a good ship and travelled home via a tramp steamer. Did Bedford similarly help the Lawsons to get home? (L. Lindsay 1967: 216; 211-12; E. Bedford 1957: 49)

If so, this shrewd businessman gained by the transaction, for Lawson recommended Bedford's manuscript to his literary agent, James Brand Pinker. True Eyes and the Whirlwind was published by Heinemann in 1903, after revision advice from Edward Garnett, which involved cutting the manuscript to 100,000 words (Barnes 2007: 102; 
Bedford 1976 [1944]: 272). The Bulletin would describe it as having a 'fairly big success in London' (1903: 13). True Eyes would be followed by a novel for Duckworth in 1905, The Snare of Strength, which was less of a success. Both books were autobiographical, very Australian, and with mining figuring large. Bedford's homesickness shows in the name of the latter's heroine: Australia (shortened to 'Stralie'). Of the two, True Eyes reads best, Vance Palmer terming it 'very dashing and robust ... at the time.' The Snare of Strength devolves into melodrama, if not quite as violent and self-revealing as his past-life imaginings in Italy. The hero elopes with Australia on his big black Arab stallion, only to die after a fall from the horse. Palmer also justly describes Explorations as 'dazzling and delightful' (22).

The Melbourne magazine Table Talk imagined Bedford in England 'floating a mine, starting a paper or standing for a seat in Parliament.' Rather more improbably it predicted he would 'try for a knighthood' (1902: 5). In the end he achieved none of these things, but did sell his novels. He also achieved a major journalistic scoop by interviewing the Pope-despite not being Catholic. It can be said that writing-wise he succeeded in England, though not with lasting literary fame. But he probably did not care. He had disliked England from first sight. Pesman comments that: 'In many ways Italy was for Randolph Bedford a stick by which to beat mother England' (15). It was what he found in Italy that enriched him the rest of his life. He had even had the opportunity to buy a castle in Italy, rejecting it because the mine that came with it was rubbish. But to stay was probably not an option for this staunch Australian patriot. Bedford, Tea with Mussolini? Not likely.

After his return Bedford would never publish another novel in England. He did write a nationalistic play 'White Australia,' produced in Melbourne in 1909, and placed three fiction books with the New South Wales Bookstall Company. Of these the most interesting was Billy Pagan, Mining Engineer (1911), a series of short detective stories which anticipates Arthur Upfield's vivid outback settings. It has been much appreciated by crime aficionados. But perhaps he did not feed the hunger to write fiction. He would be elected to the Queensland State Parliament in 1923, the same year he got involved with a worthwhile mine, at Mt Isa, and remained a parliamentarian until his death in 1941. He did not change his masculinist stripes; being an effective, active, individualist and Australian patriot, his contradictions intact to the end. 
He paid the Italians he encountered in his mine-hunting his highest compliment, wishing they could share Australia too: '[T]he rural Italian-hard-working, sober, and frugal - will be a fine settler for Australia. There are few English agriculturalists worthy the name whom we are likely to get - the bulk of the English have been stunted and starved in the cities and a great many of them are not worth the passage money' (1914: 132). Had he lived longer he would have regarded the post-World War II Italian migrations to Australia with pleasure. In fact overwhelmingly he associated Italy with pleasure, from the sybaritic to the aesthetic:

I had thought that having once felt the beauty of the art of Italy that never again should I be satisfied with a country that is sordid in many ways. But Art merely imitates the beauty of primitiveness; and my land is beautiful in its every rock and tree-even if only because of its illimitable spaces. And all are of equal value in their kind; Ghiberti's doors and Freeling Heights; Giotto's tower and Pichi Richi Pass, the brown walls of Florence and the hills at Patsy's Springs; Fowler's Gap and the Simplon Arch that dominated Milan. (1914: 240)

Italy had enhanced Bedford's life, and he would remember it affectionately ever afterwards, not least for enhancing his appreciation of Australia. He would never return to Italy; but his sojourn there had had the effect of producing of what can be regarded, in retrospect, as his best writing.

\section{Acknowledgements}

The research for this article was undertaken through an Australian Research Council grant, with Associate Professor Meg Tasker, University of Ballarat, Victoria.

\section{Reference List}

Barnes, J. 2007, 'Henry Lawson and the "Pinker of Literary Agents,"' Australian Literary Studies, vol. 23, no. 2: 89-105.

(ed.) 1981, Joseph Furphy. University of Queensland Press, St Lucia.

Bedford, E. 1957, 'The Man in the Big Hat,' Bulletin, 7 August: 32-33: 49.

Bedford, R. 1902, 'Explorations in Civilization,' Bulletin, 15 November: 32. 1903a, 'Letters from Exile,' Critic, 10 October: 13

1903b, 'London Glimpses,' Bulletin 13 June: 35

1903c, True Eyes and the Whirlwind. Heinemann, London.

1905, The Snare of Strength. Duckworth. London.

1914, Explorations in Civilization. Syd. Day, Sydney.

1976 [1944], Naught to Thirty-Three, $2^{\text {nd }}$ edition. Melbourne University Press, Melbourne.

Boland, R. G. 1979, 'Bedford, George Randolph (1868-1941),' Australian Dictionary of Biography, National Centre of Biography, Australian National University. Online, available:

http://adb.anu.edu.au/biography/bedford-george-randolph-5181/text8709 [accessed 23 November 2011].

British Australasian 1901, 7 November: 1986.

Bulletin 1902, 4 January: 13. 1903, 14 April: 13.

Carlyle, T. 1837, The French Revolution. 3 volumes. Chapman \& Hall, London. 
Dunstan, K. 1979, Ratbags. Golden. Sydney.

Lawson, B. 1943, My Henry Lawson. Johnson, Sydney.

Lindsay, L. 1967, Comedy of Life. Angus and Robertson, Sydney.

Lindsay, N. 1965, Bohemians of the Bulletin Angus and Robertson, Sydney.

Morton, P. 2011, Lusting for London: Australian Expatriate Writers and the Hub of Empire, 1870-1950. Palgrave Macmillan, London.

Palmer, V. 1963, 'Randolph Bedford,' Overland, no. 26: 21-22.

Pesman Cooper, R. 1990, 'Randolph Bedford in Italy,' Overland, no. 120: 12-16.

Table Talk 1902, 9 January: 5.

Tasker, M. \& Sussex, L. 2007, “"That Wild Run to London”: Henry and Bertha Lawson in England,' Australian Literary Studies, vol. 23, no. 2: 168-86.

Taylor, C. 1999, 'Randolph the Reckless: Explorations in Australian Masculine Identity,' in Australian Writing and the City, (eds) F. De Groen \& K. Stewart. Association for the Study of Australian Literature, Sydney: 38-45. 